\title{
CMA president-elect traverses wildernesses
}

$\mathrm{D}$ r. Anna Reid thought she was done with all things political. Back at Kootenay Lake Hospital in Nelson, British Columbia, she had served as chief of staff, as chair of the quality assurance committee and as president and chair of the medical advisory committee. It had been difficult at times. She felt committee-ed out.

In 2008, when she accepted a position at Stanton Territorial Hospital in Yellowknife, Northwest Territories, she was determined to focus on the clinical side of her profession and leave the politics to others.

Well, maybe not that determined.

"It's in my nature. I can't sit still. I have to poke my nose in and help things work better," says Reid, who was officially chosen on Aug. 23 as president-elect of the Canadian Medical Association at its 144th annual general meeting in St. John's, Newfoundland and Labrador.

Reid's journey back to the political side of medicine began when a colleague asked her to help the Northwest Territories Medical Association. Then, in 2009, when she was asked to replace the president of the association, who had stepped down, she again agreed. She had been told, after all, that the voluntary position would only consume a few hours of her week.

"That was a lie," says Reid, laughing. "There were lots of meetings with the department of health. I was involved in health promotion, and there were lots of trips to CMA meetings. It takes a fair amount of time, but it's a labour of love."

Her role as president of the Territories association led to participation in the development of CMA's policy document on health care transformation. And the more she got involved, attending meetings and forums, the more interested she became in how CMA operates. "I saw that a lot of good work was being done, and I thought I had the skills to take on the challenge of being president. I put my name forward and was honoured and humbled to be voted in by my col-

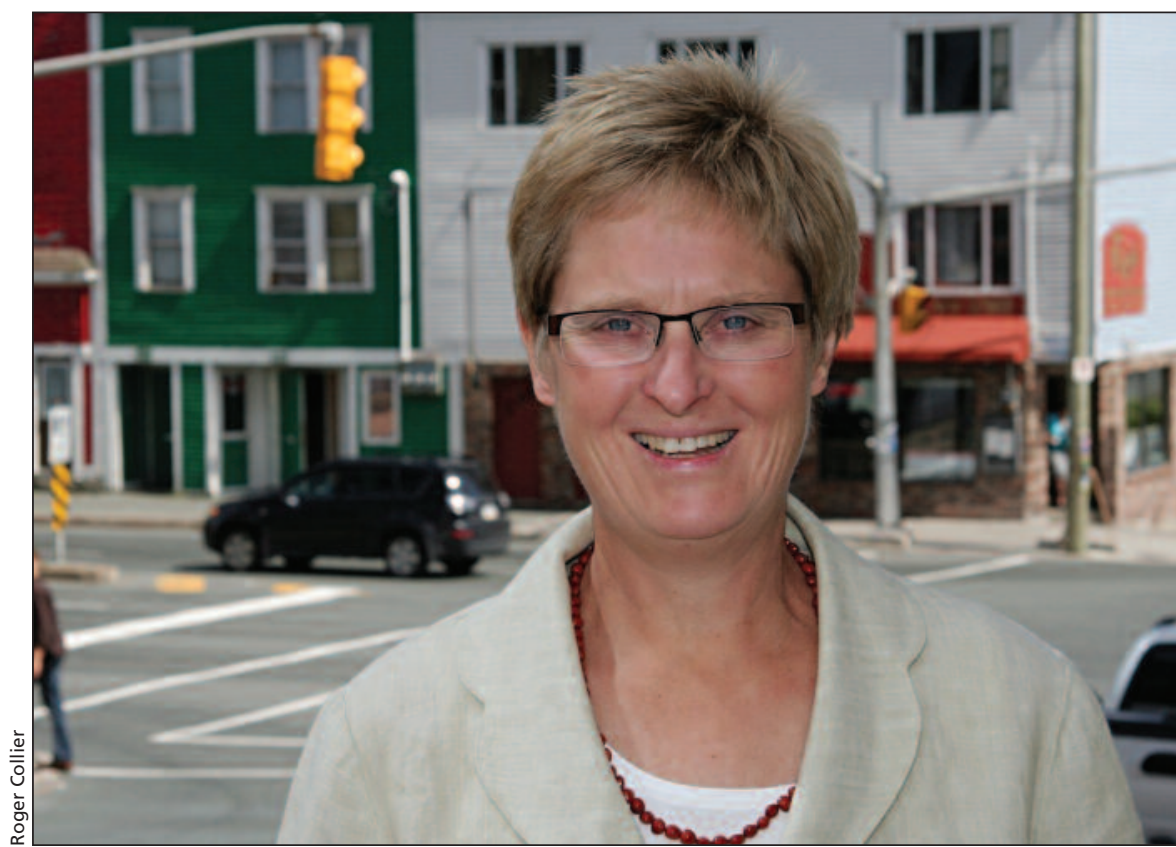

"I can't sit still. I have to poke my nose in and help things work better," says Canadian Medical Association President-elect Dr. Anna Reid.

leagues up here," says Reid, who practises both emergency medicine and hospitalist work. "It's the first time the president will be from the Northwest Territories, and it's a huge thing for us, given that we are so small."

When she assumes the CMA helm next year, Reid hopes to advance the implementation of the principles set out in the CMA's transformation initiative, which she describes as a "fabulous document."

Reid is also interested in Aboriginal health issues. The health outcomes of Aboriginal populations are "abysmal" compared to other Canadian populations, she says, a problem that "desperately needs to be addressed." She also believes the quality of health services in remote communities needs to be improved and plans to work on these and other issues when she assumes the presidency, a position she is looking forward to filling.

"I think it's going to be a huge, huge, massive challenge. It's going to stretch my leadership skills to the max, but I think I can do it," says Reid. "I'm really excited. I enjoy networking with people and I enjoy communicating. And I'm very passionate about our health care system and trying to make it work better."

Of course, Reid is familiar with addressing big challenges. In the Northwest Territories, they abound. Suicide rates are far above the national average. Many remote communities don't have access to care. Even communities large enough to support a physician have trouble attracting one. Then there is the language barrier.

"A huge percentage of the population is Aboriginal, and we have eight official languages," says Reid. "There are a lot of challenges with language barriers. Different Aboriginal groups can't speak to each other, so communication is a big issue. And there are many different approaches to death and dying. Much of the teaching in these areas is done through storytelling. Sometimes the best way to talk about something is to tell a story about it."

The Nairobi, Kenya-born Reid's affinity for medicine may have begun shortly after she moved to Ontario at the 
age of six and began sporadically visiting her great-uncle's anatomy lab at the University of Toronto, which spurred an interest in how the human body works.

That interest took a temporary backseat to her love of the outdoors and wildlife. She received a degree in wildlife biology in 1981 from the University of Guelph in Ontario. Her interest in healing the human body was rekindled when she studied emergency medicine for lay people to prepare for wilderness expeditions and she subsequently obtained a medical degree from the University of Ottawa in Ontario in 1986. Reid has volunteered in Nepal and worked in rural British Columbia and the Northwest Territories.

When she isn't working, Reid, born in 1958, enjoys spending time with her dog, Ella, and getting back to nature. She often goes paddling on Great Slave
Lake with her partner, Linda Kalbun, an occupational therapist.

"We always spend a lot of time in the outdoors," says Reid. "I've always been drawn to more remote places instead of cityscapes. I like the medicine better here, too. Even as a general practitioner, you get to do everything." - Roger Collier, CMAJ

CMAJ 2011. DOI:10.1503/cmaj.109-3981 